\title{
LITIGATION DILEMMAS: LESSONS FROM THE MARCOS HUMAN RIGHTS CLASS ACTION
}

\author{
Nate Ela* \\ University of Wisconsin-Madison
}

How do activist plaintiffs experience the process of human rights litigation under the Alien Tort Statute (ATS)? Answering this question is key to understanding the impact on transnational legal mobilization of Kiobel $v$. Royal Dutch Shell, in which the US Supreme Court sharply limited the scope of the ATS. Yet socio-legal scholars know remarkably little about the experiences of ATS litigants, before or after Kiobel. This article describes how activist litigants in a landmark ATS class action against former Philippine President Ferdinand Marcos faced a series of strategic dilemmas, and how disagreements over how to resolve those dilemmas played into divisions between activists and organizations on the Philippine left. The article develops an analytical framework focused on litigation dilemmas, to explain how and why activists who pursue ATS litigation as an opportunity for legal mobilization may also encounter strategic dilemmas that contribute to dissension within a social movement.

\footnotetext{
* Nate Ela is a PhD Candidate in the Department of Sociology at the University of Wisconsin-Madison. Please direct correspondence to nela@wisc.edu. For thoughtful comments on prior drafts of this article, I thank Meghan Morris, Joel Rogers, Erik Olin Wright, the anonymous reviewers for Law and Social Inquiry, and, especially, Sida Liu. I am grateful to Tyler Giannini, Paul Hoffman, David Kennedy, Mindy Roseman, and Lucie White for their encouragement and support of this project. A summer fellowship from the Human Rights Program at Harvard Law School provided assistance with fieldwork. I am in the debt of the staff of Task Force Detainees of the Philippines, and the many people who shared their stories with me in the Philippines and beyond - without their generosity, this article would not have been possible.
} 


\section{INTRODUCTION}

How do activist plaintiffs experience the process of litigating human rights claims under the Alien Tort Statute (ATS)? In 1980, Filartiga v. Peña-Irala held that this 1789 statute permits federal courts to take jurisdiction over tort claims by non-US citizens alleging the violation of certain well-established human rights norms. For 35 years, the ATS has offered activist litigants and cause lawyers the opportunity to use transnational human rights litigation to mobilize social movements. Yet socio-legal scholars know little about how activist litigants have experienced the process of bringing an ATS lawsuit, and how transnational legal mobilization informs relations between social movement activists and organizations.

A fuller appreciation of these dynamics would shed light on the implications of Kiobel v. Royal Dutch Shell, a 2013 case that sharply restricted the scope of ATS jurisdiction. Since Filártiga, federal courts had accepted jurisdiction over ATS claims brought by non-US citizens, even when the defendants were also foreign citizens and the alleged abuses took place on foreign soil. In Kiobel, the US Supreme Court held that the presumption against extraterritorial application of US law applies to ATS claims. This dismantled part of the legal opportunity structure (Vanhala 2012) that transnational activists and cause lawyers had constructed since the late 1970s.

After Kiobel, lower courts began to dismiss "foreign cubed" ATS suits those brought by foreign plaintiffs against foreign defendants, for conduct that occurred overseas. In the surviving cases, courts remain divided over whether the ATS applies to corporate defendants (Green 2014), and what is required for an ATS claim to displace the presumption against extraterritoriality (Bellinger 2014). Human rights lawyers, meanwhile, are considering a turn toward state courts, where they could file claims based on transitory tort theories (Hoffman and Stephens 2013). In sounding a death knell for foreign-cubed ATS cases (Curran and Sloss 2013), Kiobel may have also rung in a new phase of human rights litigation in US courts.

Appreciating the full significance of Kiobel for social movements requires understanding the baseline: how the ATS affected legal mobilization during its modern heyday. This in turn requires better understanding how activist plaintiffs experience the process of ATS litigation. From a litigant's perspective, how does an ATS suit affect dynamics of mobilization? How may it create leverage for mobilization, as well as dilemmas or unintended consequences?

Socio-legal scholars have focused on opportunities ATS litigation opens up for activist litigants (Holzmeyer 2009; Dale 2011), paying less attention to difficulties it may pose. This is understandable. The ATS has helped activists seek accountability from former state officials (Aceves 2007) and corporations 
(Redford and Stephens 2008). Even without interviewing ATS litigants, sociolegal scholars have observed how ATS cases have drawn publicity, helped build organizations, and cultivated rights consciousness (Holzmeyer 2009; Dale 2011).

Yet few socio-legal scholars have asked how litigants themselves have experienced ATS litigation. Instead, we hear from activist plaintiffs in works written by ATS cause lawyers, or by legal scholars who have worked closely with them (Lutz and Sikkink 2001; Collingsworth 2002; Aceves 2007; Redford and Stephens 2008; cf. Bennoune 2011). These studies tend to confirm the sense that the ATS aids mobilization. But since activists' accounts are themselves mobilized by legal entrepreneurs involved in constructing the field of human rights, it is reasonable to ask if "the choice of empirical terrain [was] informed by the convergence of scientific and political agendas" (Dezalay and Madsen 2012, 447).

If socio-legal scholars invited ATS litigants to reflect on their cases, what would we hear? In this article, I suggest we might hear stories that are more complex and ambiguous than those recounted by prior studies. A case study of the landmark ATS suit against former Philippine president Ferdinand Marcos suggests that listening to litigants' voices could underscore the complicated, and at times contradictory, role the ATS has played in social movement mobilization.

In 1986, Ferdinand Marcos was ousted from power and fled from Manila to Hawaii. Soon thereafter, several lawsuits were filed in federal courts, alleging he was liable for widespread human rights abuses in the Philippines during his years in power. After the former president died in 1988, the Marcos litigation ${ }^{1}$ proceeded against his estate. It became a landmark: the first ATS lawsuit brought against a former head of state; the first ATS class action; the first ATS suit decided in a jury trial. In the early 1990s, juries awarded punitive and compensatory damages of nearly $\$ 2$ billion, which at the time were the largest in US history. The litigation showed that ATS suits could be incredibly lucrative, for plaintiffs and attorneys alike. (Yet as of 2016, the lead attorney is still searching for assets against which to execute the judgments.)

The Marcos litigation created opportunities for mobilization. But in pursuing those opportunities, the radical activists who initiated the case encountered a series of strategic dilemmas - some of which arose precisely because the litigation, an unexpected success, created huge economic stakes. When activists recognized these stakes, and confronted these dilemmas, they often disagreed over the best course of action. As they did so, the litigation contributed to growing divisions and conflict within and between activists and organizations in the Philippine left.

The lesson of the human rights litigation against Ferdinand Marcos is not that seizing the opportunities created by the ATS will necessarily tear a movement apart. Nor is my claim that the Marcos litigation is representative of all ATS cases. Rather, the lesson for scholars is that we should listen to activist litigants, and be 
just as attentive to the dilemmas and contradictions of legal mobilization via international human rights litigation as we have been in studies of domestic civil rights litigation (Scheingold 1974; McCann 1994; Albiston 2011; NeJaime 2012). For activists and attorneys, the lesson is to anticipate how ATS litigation can create both opportunities and dilemmas for a movement.

I proceed by developing a framework that conceptualizes the litigation process as a series of strategic dilemmas for activist plaintiffs. This offers a new perspective on transnational legal mobilization using the ATS. After describing research methods, I present and analyze a case study of the Marcos litigation. I explain how it generated three types of dilemmas for movement activists, and examine four factors that help explain why the Marcos litigation presented activists with not only opportunities, but also sharp and divisive dilemmas. I conclude by suggesting that post-Kiobel human rights litigation will likely continue to pose dilemmas for transnational activists.

\section{LITIGATION AS DILEMMA}

Litigation is a source of strategic dilemmas. Legal and socio-legal scholars have focused on how lawyers negotiate dilemmas during litigation (Ward 1988; Weinstein 1994; Lakhani 2013). Cause lawyers face difficult decisions when working for, and sometimes with, social movement activists (Sarat and Scheingold 2005). These involve using power on behalf of activists who value equality (Shdaimah 2005), or settling a case that benefits clients, but foregoes a legal precedent (Albiston 1999). When lawyers negotiate these dilemmas by treating activists as legal subjects who lack their own voice, they risk creating tensions with their clients (Marshall and Hale 2014, 311).

Class actions are particularly problematic for cause lawyers. They may end up "serving two masters" - abstract ideals of social change, and the needs of particular clients (Bell 1976). Some avoid the difficult work of organizing by choosing to represent a class of individuals, rather than an activist organization (Southworth 1999, 2472). Here they are similar to class counsel generally, who have little incentive to collaborate with organizations of plaintiffs (Garth 1992). As a result, cause-oriented collective litigation can lead to rifts between lawyers, organizational clients, and other movement organizations (Meili 2005, 394-95).

Activists also grapple with dilemmas during litigation. NeJaime (2012) has recently outlined what he terms "the legal mobilization dilemma" by reference to the experience of activists for LGBT rights. Such activists may be attracted to litigation as a strategy to drive social change, but "the openness and accessibility that make courts so appealing ... also yield risks of movement conflict and fragmentation" (NeJaime 2012,665). Since practically any activist can file a lawsuit that claims to speak for a movement, tactical disagreements 
between activists may play out in the context of litigation, and a lawsuit can redirect a movement's strategic trajectory (id.).

NeJaime's legal mobilization dilemma helps tie together dynamics sociolegal scholars have observed in other contexts. Milner (1986, 105-6), for example, observed that mental patient liberation activists who pursue litigation are forced to choose between a "myth of rights ideology" and a "direct action ideology." And McCann (1994, 149-50) noted how, in choosing whether or not to litigate, pay equity activists faced risky decisions: legal victories can be transformative, but may increase dependence on the state; losses may destroy morale and exhaust resources. In short, litigation and the dilemmas it presents "can change social movements from within in deeply constitutive ways even as they wield it to victory" (Albiston 2011, 77).

Here I analyze a series of distinct dilemmas that activists confront and negotiate during ATS litigation. This approach understands such dilemmas as part of a disputing process (Nader and Todd 1978; Felsteiner, Abel, and Sarat 1980/1981; Bumiller 1987). Following insights developed by Merry (1990), I investigate how the process of litigating an ATS claim can move a dispute in unanticipated directions, and how litigants may lose control of their narratives leading to outcomes that legal experts see as proper, but that activists find deeply unsatisfying.

I explain litigation dilemmas in the Marcos litigation by reference to a processual framework that integrates insights from both socio-legal studies and scholarship on social movements (Barclay, Jones, and Marshall 2011). This helps explain litigation not only as a part of a political opportunity structure (Kriesi 1995; Tarrow 2005), but also as a structured social process that may influence the visions of, and relationships between, social movement activists and organizations. Political sociologist Adam Przeworski's (1985) study of the strategic dilemmas radical leftist movements grappled with when engaging liberal state institutions - albeit in a very different context - provides inspiration for this framework.

We can analyze three types of dilemma that radical activists may confront during litigation by analogy to those described by Przeworski (1985). Leaders of European socialist movements, Przeworski argues, confronted three dilemmas as they tried to advance their cause via the electoral process. First, they had to decide whether to participate in elections or to abstain. Both carried risks. Participating risked legitimating the electoral game, and the potential cooptation of revolutionary parties. Abstaining risked foregoing the real, tangible benefits that participation made possible; other parties would deliver the goods. The opportunity costs of abstaining pushed socialists to participate.

Rights ligation can pose a similar dilemma for radical activists. If they opt not to litigate, they miss a chance to deliver symbolic and material benefits to 
movement members. But if they file suit, they risk legitimating the rules of the litigation game and being coopted.

In both elections and litigation, participation leads to a second dilemma, involving representation. In Przeworski's case, party leaders had to decide whether to seek to represent a pure working-class base, or forge a cross-class coalition. The former strategy allows a party to remain true to its core supporters, but at the expense of winning the majority needed to control government. The latter could win a majority, but risks diluting the base. It also requires representing the party as wholeheartedly committed to the rules of the parliamentary game, even if the initial impetus to participate was to score propaganda points.

In litigation, the representation dilemma differs somewhat from the electoral analogue. There is, of course, no direct parallel to the choice between electoral strategies. But, as I explain through the case study, a class action does present two representation dilemmas:

a) whether to select movement leaders as lead plaintiffs, or to choose representative plaintiffs whose political commitments are less obvious;

b) whether to delegate control to a "hired gun" attorney, or have a social movement organization and its cause lawyers represent members of the plaintiff class.

Finally, if activists are successful in elections or litigation, they encounter a third type of dilemma: whether to compromise. In Przeworski's case, refusing to compromise leads to worsening economic conditions, which increases the risk of losing the next election. But compromising, and making capitalism work better, risks betraying revolutionary commitments.

In litigation, the dilemma is whether or not to settle. A settlement provides certainty that litigation will deliver some economic benefit to constituents, but may jeopardize a symbolic victory. Refusing to compromise can preserve a symbolic victory, but leaves immediate benefits sitting on the table, and risks that a later judgment or settlement offer will be no better.

Elections and litigation are obviously very different contexts for activism. But stepping back, we can see Przeworski's case as examining one series of strategic dilemmas that radical activists may confront when they engage the institutions of a liberal state. Activists who take advantage of the processes made possible via a liberal judiciary may encounter an analogous set of dilemmas. Whether we think of activists as engaging with a political opportunity structure (Kriesi 1995; Tarrow 2005) or a legal opportunity structure (Vanhala 2012), the process of mobilizing a movement by using the openings created by state institutions can force activists to make hard decisions, and reckon with how committed they are to their original strategies, visions, and alliances. 


\section{Rethinking the Role of ATS Litigation in Legal Mobilization}

Litigation dilemmas offer a new perspective on the dynamics of transnational human rights litigation. Most studies have understood ATS litigation as a source of opportunities for activists; only a few have suggested it might also be a distraction. The lens of litigation dilemmas suggests that using the ATS to create mobilization opportunities can trigger a series of hard decisions over which activists may disagree - creating the potential both to divide and to mobilize a movement.

Considering how many scholars have critiqued rights litigation and human rights activism as potential distractions from struggles for social change, it is remarkable how few have seen ATS litigation in a similar light. Critics of rights litigation have claimed that it can lead activists to develop a misplaced faith in the "myth of rights" (Scheingold 1974, 5), allow lawyers and rights discourse to coopt and deradicalize a movement (Gabel 1984; Tushnet 1984; Duncan Kennedy 2002), or place "hollow hope" in the ability of courts actually to implement social change (Rosenberg 1991). Critics of human rights activism, for their part, have argued it can construct depoliticized and individualized legal subjects (David Kennedy 2004); promote notions of the state as savage, victims as powerless, and cause lawyers as morally-superior saviors (Mutua 2002); and replace class-based utopian visions with an ostensibly apolitical legal utopia (Moyn 2010).

ATS litigation has been largely impervious to such critiques. Some critics have argued that ATS lawsuits promote judicial imperialism (Mattei and Lena 2001; Posner 2013), but few have suggested it could distract activists from better avenues for advancing their causes. John and Jean Comaroff $(2009,57-58)$ have perhaps ventured the furthest. They suggest that ATS lawsuits may be spurred on in part by a "fetishism of the law," and an "almost occult faith in its capacity." They describe the ATS as an instance in which "the law represents itself as an instrument of empowerment," even though "it oftentimes is just the opposite." Yet the Comaroffs cite just one ATS lawsuit, in passing. If we were actually to interview activist ATS litigants, would we find that they fetishized the law, or found it to be disempowering?

Many studies of ATS litigation suggest we might not. These describe ATS litigation as often being "linked to political efforts to obtain publicity" (Johnson 2004, 669-70; Dale 2011, 171), which can help activists to achieve their goals indirectly (van Schaack 2004, 2338-47; Holzmeyer 2009). Such observations align with the notion that activists harness transnational litigation for its "boomerang effects" on domestic politics (Keck and Sikkink 1998, 12; Lutz and Sikkink 2001,30), and with the legal mobilization framework proposed by McCann (1994). That approach recognizes the constraints of the legal process and courts' limited ability to implement social change, but focuses on how activists use opportunities made available by litigation to generate media and lobbying 
strategies that pressure political actors, or to cultivate rights-based legal consciousness among movement members. When activists exploit such opportunities, even cases that lose in court can help advance struggles for social change - a process NeJaime (2011) has termed "winning through losing."

There is some empirical support for this view of ATS litigation, especially from a case study by Holzmeyer (2009) of Doe v. Unocal (1997), a suit brought by Burmese plaintiffs against a multinational oil company for its alleged role in forced labor and other abuses. Through interviews with cause lawyers, corporate accountability activists, and Burmese democracy campaigners, Holzmeyer finds that activists used the opportunities afforded by ATS litigation - for increasing organizational capacity, building transnational networks, appealing to the media, and cultivating rights consciousness - to mobilize a movement against what she terms "neoliberal globalization."2 Holzmeyer $(2009,301)$ concludes that "a transnationally attuned legal mobilization framework, rather than the analytical tools of legal realist or [critical legal studies] scholars, is most appropriate to evaluating" the "indirect impacts" of Unocal and similar ATS litigation. ${ }^{3}$

It is difficult to know how far Holzmeyer's conclusion can be generalized. What might distinguish an ATS lawsuit from Unocal in a way that matters for how activists experience the process, and how scholars understand its role in legal mobilization? The case study of the Marcos litigation allows us to explore several possibilities. First, the Marcos litigation involved an ATS class action, which MacKinnon $(2000,573)$ has suggested may "further the deprivation of humanity that human rights law promises to restore," by forcibly lumping plaintiffs into a group-based class. Second, the Marcos class action was not litigated by a cause lawyer, but rather an attorney who opposed activists' efforts to use the case to advance a political cause. Third, the litigation targeted a former president, rather than a corporation. And finally, it arose out of a very different political and movement context. Activists' experiences of the Marcos litigation suggest that each of these factors may sharpen the dilemmas that activist plaintiffs encounter when they seek to use ATS litigation as a basis for mobilization.

\section{METHODS AND DATA}

This study analyzes an extreme case - one that can reveal more information than a typical case by "activat[ing] more actors and more basic mechanisms in the situation studied" (Flyvberg 2006, 229). In examining such a case, the aim was to let the facts unsettle any prior assumptions (Riles 2011) particularly whether the ATS does or does not aid mobilization. Rather than seeking universal answers about the ATS and legal mobilization, the case study opens new questions that researchers can take up in studying other cases of transnational legal mobilization (id., 13). 
My goal was to have activist plaintiffs reflect on ATS litigation, through in-person interviews. This posed challenges. Many plaintiffs live overseas, since the ATS only permits suits by non-US citizens. Some use pseudonyms to protect their security (Greer 2001), making them difficult to locate. Interviews thus require both extensive travel and the trust of attorneys and rights groups that serve as gatekeepers. Attorneys and clients have little incentive to speak with researchers before a final judgment. ${ }^{4}$ Since ATS suits often take over a decade to litigate, interviews with litigants become exercises in oral history.

Perhaps for these reasons, very few socio-legal scholars have interviewed ATS plaintiffs. Bennoune (2011) appears to have published the only socio-legal study based on interviews with more than a few plaintiffs (cf. Claude 1983). Socio-legal studies based on interviews with ATS attorneys and rights activists are more common (Holzmeyer 2009; Dale 2011), as are studies by litigators and legal academics who worked on ATS cases and then interviewed clients (Lutz and Sikkink 2001; Coliver, Green, and Hoffman 2005; Aceves 2007; Redford and Stephens 2008). ${ }^{5}$

The Marcos litigation was selected for the likelihood that its complex and ambiguous outcomes could offer new insights into the dynamics of ATS litigation and movement mobilization. The litigation, filed in 1986, led to a final judgment and several legal precedents in the mid-1990s. At the time of fieldwork in 2006 and 2007, I hoped participants would feel comfortable reflecting on the litigation's successes, and its failure at that point to deliver any compensation. ${ }^{6}$ Since the cases involved struggles between left-leaning movement organizations in the Philippines, they seemed to offer a window into the complex dynamics of using the ATS as a tool of legal mobilization.

To identify potential respondents, a snowball sample worked outward from plaintiff-side human rights litigators, who provided introductions to clients and colleagues. ${ }^{7}$ A review of the docket and court filings then identified other key participants. Additional respondents were identified by searching a comprehensive collection of Philippine and US newspaper articles on the litigation. ${ }^{8}$ I then selected respondents, focusing on those who had participated in debates and decisions concerning litigation and movement strategy. ${ }^{9}$ This led to a purposive focus on people who had led human rights organizations.

I deliberately selected respondents from both sides of a schism that split Philippine leftist movement organizations in the early 1990s, just as the Marcos litigation went to trial (and which persists to the present). On one side are reaffirmists, who reaffirm the ideological and political line of the Communist Party of the Philippines (CPP). On the other are rejectionists, who reject the CPP's stances (Weekley 1996). There is virtually no overlap; during fieldwork respondents would often tell me whether an individual, movement organization, or political party was reaffirmist- or rejectionist-aligned. 
I interviewed thirty-one participants in the Marcos litigation. One was an individual plaintiff, nineteen had filed claims in the class action, twelve had been leaders of plaintiffs' or human rights organizations, four were plaintiffs' attorneys, and five had been Philippine politicians or state officials (some had multiple roles). The respondents are likely more educated, politically active, and urban than the typical class action claimant. Most interviews took place in the Philippines, with additional interviews in the United States and the Netherlands.

I first asked participants to narrate their role in the litigation. Follow-up questions elicited views on the opportunities and difficulties that the case created for activists and organizations, and the respondents' impressions of the lawyers. I contextualized and cross-checked interview data through an extensive review of articles from Philippine and US newspapers, and court filings. Such checking was important in a context where respondents might construct accounts to shed the best light on their decisions, or might simply fail to recollect events that occurred many years earlier accurately. ${ }^{10}$ These documents also provided additional perspectives when the accounts of reaffirmist- and rejectionist-aligned respondents diverged.

With two exceptions, I use pseudonyms when quoting from interviews with respondents, and deliberately leave their organizational roles somewhat vague. The exceptions - class counsel Robert Swift and CPP founder Jose Maria Sison - are public figures who have repeatedly commented publicly on the litigation. I do not use pseudonyms when quoting from court transcripts.

\section{DILEMMAS IN THE MARCOS LITIGATION}

As the litigation against Marcos proceeded, anti-Marcos activists confronted three types of litigation dilemma: whether or not to participate, who should represent class members, and whether or not to settle. I analyze each in turn.

\section{The Participation Dilemma: To Play the Game, or Sit Out?}

In March of 1986, the People Power Revolution ousted Ferdinand Marcos from the Philippine presidency. Robert Swift, a partner in a Philadelphia plaintiffside class action firm, read the news in the New York Times. Marcos had fled to Hawaii, and when Swift learned of the abuses that had occurred under the Marcos regime - thousands of dissidents reportedly detained, tortured, and disappeared during a period of martial law that lasted from 1972 to 1981 - he realized it might be possible to use the ATS to build a mass tort class action (Interview with Robert Swift, Philadelphia, Mar. 22, 2007). He bought a ticket to Manila.

Before Swift's arrival, anti-Marcos activists had not heard of the ATS, or contemplated suing Marcos in a US court. This changed when Swift met with board members of SELDA, ${ }^{11}$ a social movement organization that advocated for 
martial law detainees and victims. Although established in 1985, SELDA had only become active since the fall of Marcos. Its founding members included former political detainees - prominent journalists, labor leaders, and dissidents. The publisher of the Manila Times chaired the board; the secretary general was a leader in the CPP and in the National Democratic Front (NDF), the coalition that had coordinated left-wing opposition to Marcos. Also on the board were the leader of a prominent union, a journalist, a Philippine navy officer who had renounced imperialism and fought against Marcos, and a college professor married to CPP founder Jose Maria Sison. The general counsel was a former television news anchor and human rights lawyer who had been arrested under martial law.

These activists had to decide whether to help Swift build a case, and to continue the struggle against Marcos in a US court. SELDA leaders appreciated that either filing a case, or not doing so, involved risks. The respondents who were involved with SELDA's decision-making told me that they didn't expect to win. Several described the case as suntok sa buwan - an expression that roughly translates as "shooting the moon."

Jovelyn, a longtime SELDA leader who was familiar with the board's deliberations, told me that winning economic damages was not the priority: The board very clearly stated to [Swift] that the objective was for the Filipino nation and the world to know that Marcos really violated the rights of Filipinos during martial law.... We wanted a documentation of these violations because to our minds there really was no systematic documentation, and the government's attitude was for us to forget - forget about the brilliant struggle, the shining struggle of the Filipinos. (Interview with Jovelyn, Quezon City, Aug. 2, 2006)

Rizal, a friend of several board members, put it more frankly. The case was "primarily for propaganda," he told me, adding that many activists "did not expect that they would win the case or that they would get anything. Some people took it as a joke.... It's more put it on record, preserve the evidence for propaganda purposes" (Interview with Rizal, Quezon City, July 9, 2006; the lawsuit was not only a propaganda mission, of course; multiple appeals and three separate jury trials - addressing liability, compensatory damages, and punitive damages confirmed its firm legal and factual bases).

SELDA's board members, like the pay equity activists described by McCann $(1994,296)$, were not "duped by either myopic lawyers or the liberal myth of rights." To the contrary, their use of litigation was politically sophisticated. They saw it as a way to "win through losing" (NeJaime 2011) using a sure-loser case to score symbolic and political points.

SELDA's leaders, part of a movement with a strong critique of US imperialism, recognized the incongruity of this approach. "To us it was ironic that 
we would be filing the case in the US," Jovelyn recalled. Yet she also felt it was "savvy," since a case could not have been filed in the Philippines (Interview with Jovelyn, Aug. 2, 2006). ${ }^{12}$ Rizal felt more strongly. "It offends my sense of national pride to go to an American court," he told me. "Why should we go there for court? The thing is to fight for rectifying the justice system in this country. This is really a mess, but we have to do it - in our country, through our efforts" (Interview with Rizal, July 9, 2006).

Seeking monetary compensation was also problematic. "We were aware that Swift was in this for the money," Jovelyn said, "and the board members thought, that, you know, the money thing was not in complete coalition with the objectives that our board members have." They decided to think of the money as "just a bonus" (Interview with Jovelyn, Aug. 2, 2006). But the notion of such a bonus troubled Rizal. "We were not fighting for ourselves," he told me. "We were not fighting for material gains. And so I don't feel nice about being personally compensated" (Interview with Rizal, July 9, 2006). ${ }^{13}$

SELDA's board ultimately chose to help Swift build a case. But Jovelyn and Rizal's accounts illustrate how SELDA leaders grappled with a dilemma. If they did not litigate, they risked losing out on opportunities to shape the historic record and tell their story through the media - propaganda opportunities. But by filing suit in the United States, they risked appearing to be mercenaries rather than freedom fighters, and passing on a chance to push for reform in the Philippine justice system. ATS litigation offered an opportunity to continue the struggle, but at least some activists saw potential downsides to its boomerang effects.

Nevertheless, the opportunities afforded by litigation, despite expectations the case would lose, appear to have convinced SELDA's leaders to work with Swift. ${ }^{14}$

SELDA's decision making suggests why activists might tend to resolve the participation dilemma by deciding to litigate. The litigation process creates opportunities to advance the interests of social movement activists, at least in the short run, even if in the long run the case seems likely to be lost. This parallels how Przeworski (1985, 10-11) sees elections: opportunities for short-term gain that workers' parties must avail themselves of. While nothing compels activists to file an ATS case, one can see why leaders of an organization like SELDA could feel pulled toward doing so.

This aligns, at least in part, with how McCann dismisses the "lure of litigation" proposition. McCann (1994, 293) describes this as the idea that "reformers beguiled by the liberal myth of rights ... tend to undermine their own efforts through reliance on lawyers and litigation." Based on his study of the pay equity movement, McCann argues that litigation is less likely to produce setbacks when movement activists and cause lawyers see it as just one tactic among many. Extending McCann's approach to a transnational context, Holzmeyer $(2009,302)$ argues that we should see activists' use of the ATS in a similar light: rather than 
being beguiled by human rights, activists use the ATS strategically, to make possible other pressure tactics.

SELDA's experience confirms that litigation can be alluring. But it is not necessarily the myth of rights that lures radical activists into filing suit. The political possibilities offered by pursuing an ATS claim can themselves be quite beguiling. Opportunities to score symbolic points can convince sophisticated activists to file a case, even when they appreciate the risks involved in doing so.

Yet even when activists' initial attitude is instrumental - rather than mystified by an "occult faith" in rights (Comaroff and Comaroff 2009, 58; Scheingold 1974, 17) - the choice to participate leads to subsequent dilemmas. This again parallels Przeworski's case $(1985,9)$, in which party leaders approached elections cautiously, swearing "only to utilize them for propaganda purposes," and vowing "not to enter any alliances with other parties or to accept any compromises." SELDA's leaders approached litigation with a similar attitude. Yet once activists opt to set a political or legal process in motion, it becomes difficult for their participation to remain purely symbolic. Material stakes arose. And when they did, activists encountered more dilemmas.

\section{Representation Dilemmas: Who Should Speak for the Class?}

By helping Swift file the class action, SELDA's leaders altered the relations between movement leaders and members in ways that they did not at first fully appreciate. Rules particular to US civil procedure structured new relations of representation, and activists confronted new dilemmas as they grappled with how to define and control these relations. Ultimately, the ways in which they responded led to a divergence from initial motivations for filing the case, and contributed to dissention and division between movement organizations.

\section{Should Movement Leaders Be Lead Plaintiffs?}

Once SELDA's board had decided to help Swift file a class action, the next step was to select lead plaintiffs, whose experiences would represent the claims of members of the litigation sub-classes. ${ }^{15}$ Again, board members faced a dilemma: should the leaders of the struggle against Marcos be chosen as lead plaintiffs? A strong case required representative plaintiffs whose experiences connected Marcos' actions, those of his subordinates, and the torture, killing, and disappearance of his opponents. Without the stories of CPP leaders who had been detained and tortured by the Marcos regime, it would be harder to draw such connections. Sison, the founder of the CPP, was one of the only people to have met Marcos in person before being tortured. But naming him or other CPP leaders as lead plaintiffs risked giving a US judge or jury the impression that the case was simply an ideologically-motivated vendetta. 
The SELDA board had to decide whether or not to include Sison in the case. Jovelyn recalled, "[Swift] said that, 'Oh, you know, Jose Maria Sison is the founder of the Communist Party, and I am afraid that he's like a lightning rod... they will inevitably say that, "Hey, this a communist," so everybody is a communist because of him." Some SELDA leaders pushed back. "The board was saying, 'But he was tortured. And for ten years he was incommunicado... That's the best example of how they can torture an individual for his political beliefs.' And [Swift] said, 'Oh, yes, but I am not keen on including him'" (Interview with Jovelyn, Aug. 2, 2006).

Swift convinced the board that Sison and other known CPP leaders should not be lead plaintiffs. Sison himself understood the decision: "I was inclined to agree, you know, for the benefit of most, no? ... I would have gladly joined the class, but I was considered [a] hot potato" (Interview with Jose Maria Sison, Utrecht, Aug. 23, 2006). As a result, the most prominent leader of the leftist movement against Marcos did not formally represent the members of the litigation class. Instead, Sison filed a separate case, as an individual plaintiff.

This decision again parallels Przeworksi's analysis of how radicals engaged with electoral systems. "A party cannot appear to be 'irresponsible,"” Przeworski $(1985,15)$ explains, or "give any indication of being less than wholehearted about its commitment to the rules and the limits of the parliamentary game." In the Marcos litigation, activists recognized that in order to seize the opportunities afforded by engaging with US courts, they could not appear to be exploiting the process for political purposes.

During depositions, defense attorneys for the Marcos estate nevertheless asked about plaintiffs' ties to the CPP. Swift asked the court to find such questions to be irrelevant, and bar them from being asked before the jury. The court granted his motion, in a decision that pleased many respondents, including Sison. "It would have confused the legal issues," Sison explained, "if, let's say, I, the victim, would rub in my ideological position and political views. The case is simply that I've been victimized, no?" (Interview with Jose Maria Sison, Aug. 23, 2006). ${ }^{16}$ But Sison acknowledged that framing the case in terms of individual rights did entail a tradeoff. "The abstraction ... is protecting the rights of the individual against the all-powerful - or against the powerful state," he observed. "That's fine, no? But there is a slurring over of the reality of class and the reality of imperialist countries and oppressed nations" (ibid.).

This "slurring over" illustrates how the case was beginning to slip from SELDA activists' original desire to use the litigation as a vehicle to tell the history of the martial law period and the struggle against Marcos. As Jovelyn stated, "I think if court records would be, you know, examined generations later, those are the stories and they are precise stories that will bear out what happened" (Interview with Jovelyn, Aug. 2, 2006). To a point, this is true. But to maximize 
the likelihood of winning the case, activists followed their lawyers' advice to select lead plaintiffs and construct the evidentiary record so as to obscure their own ideological and political commitments. ${ }^{17}$ Rather than represent themselves as part of a movement that fought, at times violently, to achieve a political utopia via a class-based revolution, SELDA and Sison agreed to present themselves as nonideological members of a class of individual victims. ${ }^{18}$ Although the opportunity for propaganda provided an impetus to litigate, maximizing the likelihood of winning entailed crafting an apolitical narrative that fit the form of human rights (Moyn 2010).

\section{Should a Movement Organization Directly Represent Victims?}

A second representation dilemma concerned the roles lawyers and movement organizations played in representing victims. In the class action context, activists must choose whether to cede control to a class attorney who may not represent their cause, or seek to have a movement organization and its cause lawyers directly represent victims. The first option leverages a class action firm's expertise and resources, but risks losing control of the case, and having a large share of the winnings enrich attorneys rather than movement organizations. The second option, organizational representation, can increase activists' control over a case (Southworth 1999). It may also give movement organizations a stake in any winnings. But in the Marcos litigation, it risked antagonizing Swift, the presiding judge, and other members of the movement.

Initially, SELDA leaders did not have much of a decision: Swift was the only lawyer at hand with the expertise and resources needed to file such a complex case. SELDA's leaders realized Swift did not share their political commitments. As one put it, Swift was "a simple lawyer out to make a fast buck," not a human rights lawyer (Interview with Arvin, Quezon City, July 31, 2006). Some activists suggested SELDA look for a different attorney, but the board soon decided to help Swift build a case (Interview with Jovelyn, Aug. 2, 2006). As a SELDA chairman later explained, the fact that the organization's general counsel was Swift's co-counsel "gave SELDA's board confidence that the interests of SELDA members were being safeguarded" - even though Swift did not formally represent SELDA as an organization (Declaration of Daniel Vizmanos 1991, paragraph 10).

Only after the court's appointment of Swift as lead class counsel, and the sudden death of SELDA's general counsel, did SELDA leaders realize that the organization lacked any official role in the case, or any real control over Swift. The lead plaintiffs were still SELDA members, but as class counsel Swift's primary duty was to protect the amorphous interests of all members of the class, not just the interests of lead plaintiffs. Romeo Capulong, a Filipino cause lawyer who served on the legal team in Sison's case, was appointed as SELDA's new 
general counsel. After Capulong learned that SELDA had never had a written contract with Swift, the board sought to put the initial verbal agreement with Swift in writing. But Swift would not sign (Interview with Angelo, Makati, Aug. 8, 2006). ${ }^{19}$

SELDA's leaders now had a decision to make. They could let Swift retain control over the case, and risk letting his decisions as class counsel take precedence over SELDA's goals for the case. Or they could try to take control, which would risk antagonizing Swift and the judge. At the beginning of 1992, just months before trial, SELDA moved to intervene as a party in the class action. Swift saw this as an attempt to usurp his role: "they basically told me, well, they're gonna handle the case from here on in" (Interview with Robert Swift, Mar. 22, 2007).

SELDA activists were no longer just shooting the moon, aiming for a symbolic victory. It had become clear that the case had potentially huge economic stakes. In SELDA's motion to intervene, the organization's leaders asserted that most class members were also members of SELDA, and stated that the organization was "interested in the manner in which the damages phase of these proceedings should be structured and in the possibility of a settlement in which its members might receive immediate redress for the injuries they suffered" (Memorandum in Support of SELDA Intervention 1992, 3). SELDA's chairman reported that class members had asked for separate representation by SELDA after the trial on the question of whether the Marcos estate was liable. "It is likely," he wrote, "that SELDA would play a major role in representing class members in the damages phase of [these] proceedings" (Declaration of Daniel Vizmanos 1991, paragraph 11).

Rules of US civil procedure, however, limit an organization's ability to sue on behalf of its members. At the time the Marcos cases were filed, an organization could only be a party when it sought prospective relief, such as a declaration or an injunction (Hunt v. Washington State Apple Advertising Commission 1977, 343). Since damages had always been the goal of the suit, Swift had never considered naming SELDA as a plaintiff. $^{20}$

With the rules in his favor, Swift easily defeated SELDA's motion. "SELDA has no claim here," the judge noted during a hearing, "so SELDA, as a party, doesn't mean anything to this lawsuit." If SELDA wanted to have a say in the trial, he reasoned, that would be possible since its new chief counsel, Capulong, also represented Sison in his individual suit (In re: Estate of Ferdinand E. Marcos Human Rights Litigation, Transcript of Proceedings, Jan. 20, 1992, 7).

Outside the courtroom, activists were struggling over the future of the Philippine leftist movement. In December of 1991, the CPP released a document titled "Reaffirm our Basic Principles and Rectify Errors." This document, signed by Sison using an alias, restated the Party's orthodox class analysis of Philippine 
society, and argued that deviations from the party line accounted for weaknesses in the movement (Weekley 1996). Throughout 1992, leftist activists debated the merits of the document, and began to split into reaffirmist and rejectionist factions.

Movement activists were now the lead plaintiffs and star witnesses in a case where the class counsel and a key movement organization had become antagonists. SELDA's leaders demanded to meet with Swift just before the liability trial in 1992. Swift recalled that the SELDA chairman said he had done a good job so far, but that Capulong would manage the case going forward. Swift replied that although Capulong had worked as an immigration lawyer in the United States during the Marcos regime, he neither had the credentials necessary to take on the case, nor had been appointed class counsel by the court. Moreover, Swift noted, SELDA did not have the funds to litigate the case. The chairman, as Swift recalled, said that SELDA would figure it out. Swift said he disagreed, and that the case would proceed (Interview with Robert Swift, Mar. 22, 2007).

Dalisay, a victim who testified in Hawaii, linked this confrontation to the unfolding political turmoil:

The Communist Party is about to split.... During the trial we're still not affected, but there was already a move. And I was among those that's hard to the lawyer [Swift]. Because I still believe in my [political] line.... Hard to the lawyer, we keep questioning him for everything.... We're just so angry with him.... Sison would want attorney Capulong to replace attorney Swift. And we were convinced to do that. Because these are Filipinos, and it should be [a] Filipino lawyer who should defend us. (Interview with Dalisay, Quezon City, June 29, 2006) Witnesses even threatened a boycott. "We want to have [a] meeting with you," Dalisay recalled that they told Swift, "or we're not going to testify in court." Swift met with them, and explained what was needed for the case to succeed. Dalisay noted that Swift fought hard to retain control over the case, which she attributed to his significant investment of time and money. Although she remained angry that Filipino human rights lawyers could not represent her, Dalisay came to realize that Swift was working to win the case for the victims. She chose to testify, and later felt "jubilant" (ibid.) to have had the opportunity to speak for others who were not able to tell their stories in court. ${ }^{21}$

Shortly after the trial, a group of rejectionists split from SELDA, forming a new organization they named Claimants $1081 .^{22}$ This move, a Claimants 1081 leader explained, reacted to SELDA's attempts to take control over the case. In a class action, as she saw it, "there are rules that have to be followed, legally speaking. And you can't go into, you know, this political whatever... It's a court case and we have to follow it. And so, we decided to organize Claimants 1081, specifically to help in the processing of the class suit" (Interview with Leizel, Quezon City, July 28, 2006). The new group established a supportive relationship 
with Swift. Another founder recalled that "it's easy for us to organize because a lot of the people who split out from the movement automatically become a member in the Claimants 1081" (Interview with Dalisay, June 29, 2006). Unlike SELDA, membership was limited to class action claimants.

The goals of Claimants 1081 fit well with Swift's understanding of the case. "Their intent," Swift explained, "is that money go to victims, and that's exactly my intent. Money doesn't go to organizations" (Interview with Robert Swift, Mar. 22, 2007). By this point, Swift had seen that SELDA "turned out to be more ideological" than some of the other claimants: "They started looking upon this as a profit center for their group and to advance their politics" (ibid.). Swift, in turn, began to coordinate his work with Claimants 1081; when he filed suit in the Philippines to enforce the US judgment, he named Claimants 1081 leaders as class representatives.

SELDA leaders also felt that money and politics had motivated the split. But in their view, Claimants 1081 leaders were seeking to benefit from the case. According to Jovelyn, the new group "broke away from us when the money thing came in... [and] partly they broke away with us because it was instigated by Swift." She added that a founder of Claimants 1081 had been considering running for elected office, and the new organization created a basis for the campaign (Interview with Jovelyn, Aug. 2, 2006). Sison noted that once "Swift got everything from SELDA, basically everything that they needed for the court case," - including lead plaintiffs and a database of potential claimants ${ }^{23}$ - he turned to a new "group [that] would be essentially focused on how to get the money" (Interview with Jose Maria Sison, Aug. 23, 2006).

SELDA, Swift, and Claimants 1081 have repeatedly wrangled over the proper role for a movement organization in the litigation. In one instance, SELDA helped distribute claim forms to potential members of the class. Included along with the claim form was another document stating that a claimant agreed to representation by SELDA in any settlement negotiations. In return, claimants were asked to pledge up to fifteen percent of any compensation to SELDA. Members of Claimants 1081 saw this as an attempt "to centralize the collection ... [and] to try to get a certain portion of the compensation into the coffers of the movement" (Interview with Bagwis, Quezon City, June 26, 2006). Swift successfully petitioned the court to bar any private attorney for a class member from receiving more than five percent of an award (Interview with Robert Swift, Mar. 22, 2007).

The dilemma of whether and how to seek representation by a movement organization arose only when activists realized that the litigation might succeed, and have real economic stakes. For SELDA, this prompted moves to intervene as a party, or otherwise provide direct representation in a way that might feed some portion of the winnings back into the movement organization. SELDA's approach 
to this dilemma, together with the ideological schism that was underway, contributed to dissension and division between members of the movement. These prompted the creation of a breakaway group, which distinguished itself by supporting Swift's authority, and renouncing efforts to channel compensation toward movement organizations.

This representation dilemma, and its potential to feed into tensions between movement factions, appears starker when one appreciates the incentives of class counsel. In a study of several types of class action, Garth $(1992,256)$ concluded that class counsel generally have little incentive to support the creation of activist organizations of plaintiffs. The Marcos case suggests that the transnational context of ATS litigation may be somewhat different, since a class counsel may depend on activist organizations to collect and disseminate information (Ratner 2003). Swift needed SELDA's help to build a case, and has worked with Claimants 1081 to communicate with claimants. Yet when SELDA appeared to be using the case to advance its members' politics, and to claim a share of compensation, Swift became opposed to its involvement. This tension between an ATS class counsel's dependence on help in gathering and sharing information and his drive to maintain control over representation and compensation may set the scene for a split between plaintiffs' organizations with different visions.

\section{The Settlement Dilemma: To Compromise, or Fight On?}

Soon after the Marcos estate was found liable at trial, Swift began seeking a settlement. From 1995 through 1999, he tried to reach an agreement with both the Marcos estate and the Philippine government, which had decreed that all recovered Marcos assets should be dedicated to a land reform program. This put radical activists who had filed claims in the awkward position of prioritizing individual compensation over land redistribution.

SELDA mobilized against Swift's settlement efforts. In one instance, Swift met with representatives of the estate and the Swiss and Philippine governments in Hong Kong, to discuss how \$650 million in Marcos assets found in a Swiss bank might be used to satisfy the judgment. Together with a migrant workers' organization, SELDA organized a rally to protest that victims were not directly involved in the negotiations. Hundreds turned out, allowing SELDA to lobby representatives from the Philippine embassy and gain media coverage in Europe, Hong Kong, and the Philippines (Interview with Jovelyn, Aug. 2, 2006). Rather than transfer the money to the court in Hawaii, the Swiss government placed it in escrow in the Philippines. This dealt Swift a defeat, since the funds could not be used to satisfy the US judgment, or to cover his fees.

Swift pushed on. By 1998, he managed to broker a $\$ 150$ million settlement with the Marcos estate and the government. At a hearing in Hawaii, the 
US court approved the agreement, but it was later scuttled by a Philippine court that barred the government from transferring funds overseas. Objections raised during the hearing in Hawaii illustrate how activists viewed the settlement as a dilemma.

SELDA leaders were especially troubled by two clauses in the proposed agreement. The first stated that Imelda Marcos and Ferdinand R. Marcos (the widow and son of the former president) maintained the innocence of the former president. The second stated that neither had ever been charged or sued for human rights violations in the Philippines. ${ }^{24}$

During the hearing, Neri Colmenares, a class member, Philippine attorney, and SELDA member, explained his opposition. He had concluded that any legal reason for the clauses was probably secondary; their real basis for their inclusion was "primarily propaganda."

The Marcoses want to refurbish their image tarnished by the verdict and the judgment of this Court and that they want to renew and cleanse it again by stating things like: That they maintain their innocence of the human rights violations. So, based on that framework I disagree with the settlement because it dilutes and nullifies the verdict and the judgment of this Court. It distorts the truth and history. (In re: Estate of Ferdinand E. Marcos Human Rights Litigation, Transcript of Proceedings, Apr. 29, 1999, 49-50)

The judge explained that the settlement would cap the total amount of funds that could be collected, but the judgment would remain in place. Colmenares was not satisfied: "the propaganda effect of the insertion ... would be so that it reverses or nullifies the historic symbol of the judgment itself." It would be, he suggested, as if the Jewish people agreed to a $\$ 1$ billion settlement with the Nazis, in which the Nazis acknowledged no fault; this simply would not be acceptable (ibid., 35). The judge replied:

The Court: Unfortunately, in the law we deal with a lot of words that really don't mean anything.... I've never seen a settlement agreement in which the defendant does not deny any liability. It just doesn't happen. It just does not happen.

Colmenares: Well, Your Honor, this is a different case, Your Honor. In The Court: No, it isn't. (ibid., 36)

Where activists like Colmenares saw a struggle over historical meaning, the judge saw a typical tort case - in which injury translates into compensation, and settlements routinely involve disclaimers of liability. For Jovelyn, this was disgraceful: "The case involves crimes against humanity. It's not as simple as [money], see? ... It's very insulting to us, that if we just show to the world that the victims filed a case with Imelda so that she can pay us" (Interview with Jovelyn, Aug. 2, 2006). 
Many Claimants 1081 members also opposed the settlement. But some felt SELDA had ulterior motives. Reaffirmists, Bagwis observed, wanted to "stretch the political mileage out of the case" and "control the mechanism for distributing the money" so that they could take part of it (Interview with Bagwis, June 26, 2006). In one episode, the reaffirmist-led NDF negotiated a peace treaty with the Philippine government, which provided that the NDF would coordinate any compensation for human rights victims. A Claimants 1081 leader argued that the lawsuit had been filed by "private individuals" in a US court, and had nothing to do with peace talks between the Philippines and the NDF (Interview with Leizel, July 28, 2006). Sison, by contrast, saw this attempt by the NDF to cut Swift out of compensation as legitimate. Swift "is a capitalist, so he says he has invested money and time and professional effort so he must collect," Sison explained. "He's a capitalist because the amount that he would get is so large ... thirty-five percent of two billion - that's something, no?" (Interview with Jose Maria Sison, Aug. 23, 2006). Sison was comfortable with blocking a capitalist from taking his profits.

Members of Claimants 1081 were more likely to support the settlement, and generally accepted that Swift himself deserved some compensation. "We have made a point already [based] on the [court's] decision," Bagwis told me, adding that "many of the claimants are already getting old - some of them have already died. They want the compensation to come [at] the earliest possible time" (Interview with Bagwis, June 26, 2006). Dalisay, who had considered boycotting the trial, now felt that Swift had earned his share. "He's a person... who is honest, sincere, and industrious in his job," she told me. "I think he is worth to be given, when he is asking, thirty percent of the amount" (Interview with Dalisay, June 29, 2006).

In successful civil litigation, the prospect of a negotiated compromise is practically unavoidable: plaintiffs are far more likely to win a tort action via a settlement than through a trial (Eisenberg and Lanvers 2009, 112-13). Although settlement is probably somewhat less common in ATS litigation, ${ }^{25}$ the prospect of compromise can pose a dilemma for activists hoping to use the ATS as a means of mobilization.

The settlement dilemma involves deciding whether or not to enter into a risky transaction. An ATS suit gives activists the opportunity to accumulate symbolic capital (status as aggrieved victims who were on the right side of history) and economic capital (monetary compensation). A settlement offers the opportunity to deliver economic benefits to movement members, but risks debasing or forfeiting symbolic capital in the exchange (Bourdieu 1986). This is particularly so when, as is customary, the transaction involves disclaiming a defendant's liability, and agreeing to keep details of the settlement confidential thereby silencing or contradicting the narrative that activists hoped to build via 
litigation. Converting symbolic into economic capital can also suggest that money, not principles, is what motivates activists. Yet refusing to settle risks passing up economic benefits, and sparking resentment among movement members who could use the help.

The class action context shapes the dynamics of this dilemma. Attorneys for individual plaintiffs must follow their clients' instructions, but class counsel have discretion over whether or not to settle. Sinking millions of dollars into litigating a class action can make them more risk-averse than class members (Coffee 2000, 389-93), and thus more likely to settle rather than take a case to trial, or (as in the Marcos litigation) pursue a seemingly endless hunt for a defendant's hidden assets. In the class context an activist's preference for preserving a judgment's symbolic value may be at odds with the class attorney's desire to recoup costs and collect fees. When class counsel can accept a settlement offer and convince a judge to approve it, activists opposed to settlement may see their stories as the subject of a forced transaction. Meanwhile, other class members may be more risk averse and prefer to settle, raising the possibility that the settlement dilemma will contribute to dividing groups of activist litigants (Rhode 1982, 1191).

These dynamics in the Marcos litigation suggest a potential twist to the paradox of losing-by-winning proposed by Albiston (1999). By the time of settlement negotiations in the Marcos litigation, the case had already set multiple legal precedents. The paradox, then, was that a win via settlement could entail losing the case's symbolic value. This was ironic, since SELDA activists had expected to win a symbolic victory by losing their case (NeJaime 2011). Winning, then, not only came as a surprise, but also as a threat to the ability to define the historical roles played by Marcos and his political opponents.

\section{Why did Anti-Marcos Activists Encounter Litigation Dilemmas?}

Regardless of its eventual outcome, the process of ATS litigation can create opportunities for mobilization (Holzmeyer 2009; Bennoune 2011; Dale 2011). This was the case for the activists who brought the ATS litigation against Ferdinand Marcos, but their experiences were more obviously marked by strategic dilemmas, and by conflict, than cases other scholars have analyzed. Why might this be? Was there something about the context of the litigation, or the way in which it was structured, that made strategic decisions especially difficult, or more likely to spur divisions?

Perhaps the Marcos litigation is an extreme case not only in that it lays bare basic mechanisms of ATS litigation (Flyvberg 2006, 229), but also in that it was unusual compared to other cases. By comparing the Marcos litigation with Doe v. Unocal - a case that legal and socio-legal scholars have taken as a successful case of legal mobilization via the ATS (Redford and Stephens 2008; 
Holzmeyer 2009; Dale 2011) - we can identify factors that may have sharpened the dilemmas that anti-Marcos activists encountered. Of course, such a comparative exercise does not control for all the variables that might affect the interaction of litigation and social movement mobilization. But it does suggest some hypotheses - points of departure to be explored in future case studies. In particular, four factors could make strategic dilemmas more pronounced for activists who would hope to use ATS litigation as a basis for mobilization.

\section{Political and Movement Context}

The historical, political, and movement context in which the Marcos class action was litigated likely increased the odds that activists would encounter dilemmas, and that those dilemmas would spark dissention and conflict. Two aspects of the litigation context are particularly notable.

First, the Philippines had been a US colony, and one of the leftist critiques of the Marcos regime was its capitulation to US neo-imperial rule. Commitments to anti-imperialism and nationalism made it difficult for some activists to rely on expert help from a US lawyer, or to seek justice in a US court. Many ATS cases arise out of disputes in post-colonial states, but in this case the specific colonial history of the Philippines likely sharpened the participation dilemma for at least some activists.

Second, the fact that the litigation was filed after Marcos left power, and continued after his death, may also have made dilemmas and conflicts more stark. With Marcos gone, leftist groups were no longer united in opposition to his rule. Instead, they were torn over how best to carry on the struggle during a more democratic period in the Philippines, and in a context where faith in, and support for, communism was collapsing in the Philippines and beyond. This likely sharpened dilemmas related to organizational representation. For activists on either side of the rejectionist/reaffirmist divide, representation by SELDA or Claimants 1081 had distributive consequences, both symbolic and economic. As Sison noted, framing the case in terms of individual rights tended to slur over efforts to build a more political narrative of the struggle against Marcos. For some Claimants 1081 activists, the litigation offered a means of distancing themselves from the more radical collective struggle for justice advocated by SELDA, in favor of a less political vision of justice rooted in individual human rights (Moyn 2010).

The Unocal litigation proceeded in a very different context. The accounts of Holzmeyer (2009) and Dale (2011) shed little light on whether Burmese plaintiffs found it problematic to work with US lawyers, or sue in a US court. But, compared to the Philippine context, it seems far less likely. Burma had not been a US colony, and filing a case in the courts of the Burmese military junta was not an option. By contrast with the Marcos litigation, it was Burmese activists who 
sought out US lawyers to investigate the possibility of an ATS lawsuit. (Collingsworth 2002; Redford and Stephens 2008)

The Unocal lawsuit proceeded while Burma remained under military control, which may also have reduced the likelihood that litigation dilemmas would have sparked conflict. Holzmeyer $(2009,283)$ notes that Burmese activists were mostly united by their opposition to the military junta, even though their visions of a future regime differed. By the time Unocal settled, organizational plaintiffs were no longer part of the case (Redford and Stephens 2008, 451), and the remaining individual plaintiffs were from the same ethnic group (Dale 2011, 151). This may also have lessened the likelihood of dilemmas and tensions.

\section{Class Action Versus Individual Suit}

The fact that the lead case against Ferdinand Marcos was framed as a class action likely also sharpened the litigation dilemmas faced by activists. Class actions in other contexts are often fraught with tensions between attorneys, class members, and organizations (Bell 1976; Southworth 1999; Meili 2005), particularly when parties' interests in a settlement diverge (Rhode 1982, 1191).

Once the Marcos litigation was certified as a class action, Swift was ethically bound to represent the inchoate interests of the class. SELDA leaders soon realized that he no longer had a duty to represent the lead plaintiffs who were SELDA members, or the organization itself. This raised the difficult and divisive decision of whether to support Swift, or seek to replace him. A representation dilemma also provoked dissension concerning settlement, when SELDA and its allies sought to give the organization a role in distributing compensation as part of a treaty with the Philippine government, while Swift and Claimants 1081 members argued that only individual claimants deserved compensation.

Swift's ability to sideline SELDA and retain control over the case fits with the observation by MacKinnon (2000) that ATS class actions can deprive litigants of control over the process. But the Marcos litigation does less to support MacKinnon's assertion that this "further[s] the deprivation of humanity that human rights law promises to restore" (573). Most SELDA activists whom I interviewed never seem to have expected human rights law to restore their humanity. They were far more pragmatic: they expected it to create opportunities to advance their cause. When it turned out the class counsel had a different vision for the lawsuit, they risked jeopardizing the case by opposing his control, both in court and in the streets. Nor did Claimants 1081 members seem to view Swift's control over the case as a deprivation of their humanity. They understood that class action procedure simply gave Swift control over the case, and they were grateful when he consulted with their organization. 
By all accounts, Unocal did not involve tensions like those that burst into public view during the Marcos litigation. It seems plausible that the plaintiffs in ATS cases against Unocal never confronted such stark dilemmas. Although Roe v. Unocal (1999) originally included labor unions as organizational plaintiffs, and Doe v. Unocal (1997) was initially filed as a class action, the district court rejected the organizational claims (National Coalition Government of Burma v. Unocal 1997), and denied the motion for class certification (Doe v. Unocal Corp. 1999). This meant that the cases against Unocal were litigated on behalf of a group of individual plaintiffs, who retained ultimate control over decisions concerning representation and settlement. When they settled, the plaintiffs and their attorneys announced a deal that funded community development programs in Burma (EarthRights International 2005) - suggesting that even though they were litigating as individuals, the plaintiffs understood themselves to be seeking compensation for a larger group.

\section{Type of Lawyer}

Litigation dilemmas in the Marcos case may also have been sharpened by the fact that Swift neither considered himself, nor was seen by activists, to be a cause lawyer. Swift welcomed support from activist organizations as he built the case. But he did not see the litigation as a vehicle to support those organizations, or to advance their political agenda. Instead, his goal was securing compensation for individuals; he defended this goal by repeatedly blocking SELDA's attempts to gain a formal role in the lawsuit. This stance sharpened litigation dilemmas related to representation and settlement. Activists had to choose between supporting Swift, whose approach might win the case but not help mobilize the movement, and trying to replace him with Capulong, a movement lawyer who might lack the expertise and resources to win. When it came to settlement, a cause lawyer who worked closely with activists might have a shared interpretation of the meaning of winning and losing (Marshall and Hale 2014, 313). A lawyer who understood the importance of using the case to shape the historical narrative of the Marcos era might have brokered a different deal, or no deal, with the Marcos family.

Plaintiffs in the Unocal litigation were represented by cause lawyers, many of whom worked for organizations dedicated to environmental justice, labor rights, and human rights. The lawyers interviewed by Holzmeyer (2009) were fine with unions joining with them in solidarity (294); felt that "using litigation in tandem with a campaign" can give that campaign "teeth" (291); and saw litigation as "a small piece of the puzzle" in a broader movement, by "call[ing] attention more broadly to abuses in Burma and U.S. corporate complicity" (292). By contrast with Swift, the Unocal lawyers actively invited opportunities for legal mobilization. 


\section{Type of Defendant}

Finally, the dilemma concerning whether or not to settle the Marcos litigation may have been sharpened by the fact that the lawsuit targeted a former state official. Because of sovereign immunity issues, ATS lawsuits generally only proceed against state officials once they are out of power. Such lawsuits can embarrass or bankrupt former officials, but have little power to affect state policy directly.

Proponents of ATS litigation sometimes suggest that suits against former officials can have a deterrent effect (Coliver, Green, and Hoffman 2005, 184). Yet none of the respondents in the Marcos litigation saw the case as having pushed subsequent Philippine leaders to respect human rights. Given that perspective, it is understandable that they would not see much upside to settling the case. Like plaintiffs in other ATS suits against former officials (Filártiga 2004; CabelloBarrueto 2014), the activists interviewed here aimed to confront an abuser and establish an official record. The potential downside of settling - and undercutting the historical narrative the case had established - was huge.

Corporate ATS cases present a different set of opportunities and risks. The Unocal case, for example, created a new way to exert pressure on a military regime, as well as corporations that do business with the regime. While the Marcos litigation set the precedent that a former head of state could be sued under the ATS, Unocal opened a new phase of human rights litigation. It created a double opportunity for mobilization, both for democracy in Burma, and, more broadly, for mandatory rules of corporate social responsibility (Dale 2011).

The decision whether or not to settle can also be difficult for activist plaintiffs in corporate ATS cases. In Unocal, plaintiffs and their allies "worried that they had allowed Unocal to buy its way out of the problem" (Redford and Stephens 2008, 460). And a lawyer in an ATS suit against Yahoo! has noted that plaintiffs "may find it difficult to decide whether such a private agreement can have the far-reaching public impact" they desire (Harris 2008, 12). Plaintiffs' attorneys, of course, face a different dilemma of "losing by winning," when a settlement offer in a case like Unocal is too good for their clients to pass up, but also keeps them from setting a legal precedent (Albiston 1999).

Compared to suits against former officials, however, the dilemma of compromise might be somewhat less sharp in corporate ATS cases. A settlement hits a company's bottom line, and is thus more likely to affect future behavior, as compared to a settlement with a former state official. A settlement may also affect other corporate leaders' risk perceptions, and their company policies (Redford and Stephens 2008, 460). Even agreements that formally disclaim liability can set precedents that alter business behavior (Cleveland 2004, 979-80). For activist 
plaintiffs, then, settling a corporate ATS case may be less problematic than agreeing to a compromise with a former government official.

\section{CONCLUSION: ATS LITIGATION AS OPPORTUNITY AND DILEMMA}

The experiences of the radical Philippine activists who sued Ferdinand Marcos suggest that even as filing an ATS suit creates opportunities for legal mobilization, the litigation process can pose strategic dilemmas. Activists may disagree over whether or not to file a case, who is best suited to represent claimants, and whether or not to settle a lawsuit. The dynamics of a movement can inform how activist litigants negotiate these strategic dilemmas, and disagreements over the right strategy for proceeding in litigation can contribute to dissension and divisions between activists and movement organizations.

Comparing the Marcos litigation with prior studies of ATS litigation suggests that these dilemmas may be sharper, and more likely to foster divisions within a movement, if a lawsuit is framed as a class action; if it is not litigated by cause lawyers; if the defendant is a former state official; or if it is brought by activists who are no longer united by opposition to a single opponent, or who are opposed to US influence in their country. These factors suggest how and why litigation dilemmas might present themselves during human rights litigation. They help explain why the Marcos litigation was a more complicated and contradictory experience for activists than those that scholars have observed in previous studies of legal mobilization via ATS litigation.

Appreciating the complex dynamics of using the ATS as a basis for legal mobilization offers a chance to reflect how activists might, or might not, face a different set of opportunities and dilemmas in years to come. In Kiobel, the Supreme Court changed the rules of the ATS litigation game, but did not end it entirely. Some lower courts have dismissed ATS cases after Kiobel because they do not sufficiently "touch and concern" the United States. But courts remain divided as to both what the touch and concern standard entails, and how to define a standard for corporate liability. Meanwhile, human rights litigators are looking to state courts as an alternative venue. Despite Kiobel, creative lawyers will continue to file transnational human rights suits, and transnational activists will keep looking to litigation in US courts as a potential opportunity for mobilization.

In pursuing human rights litigation in US courts, activists will likely continue to face dilemmas. Kiobel, after all, has not altered the four factors considered above. ATS cases may still be framed as class actions; they may still be brought against corporations or former state officials; they may still attract both cause lawyers and hired guns; and they will still play out against a variety of political contexts. The same goes for human rights cases framed as transitory torts, and filed in state courts. There is little reason to suppose that Kiobel will make the social movement dynamics of human rights litigation in US courts any 
less complex than they have been in the past. In the years to come, transnational activists will continue to avail themselves of the opportunities for mobilization created by litigation in US courts. And in the process, they will be likely to encounter litigation dilemmas. 


\section{REFERENCES}

Aceves, William J. 2007. The Anatomy of Torture: A Documentary History of Filártiga v. Peña-Irala. Leiden: Martinus Nijhoff.

Albiston, Catherine. 1999. The Rule of Law and the Litigation Process: The Paradox of Losing by Winning. Law \& Society Review 33:869-910.

------. 2011. The Dark Side of Litigation as a Social Movement Strategy. Iowa Law Review Bulletin 96:61-77.

Barclay, Scott, Lynn C. Jones, and Anna-Maria Marshall. 2011. Two Spinning Wheels: Studying Law and Social Movements. Studies in Law, Politics, and Society 54:1-16.

Barrett, Paul M. 2011. Amazon Crusader. Chevron Pest. Fraud? Bloomberg Businessweek, March 9. http://www.bloomberg.com/bw/magazine/ content/11_12/b4220056636512.htm (accessed May 25, 2015).

Bell, Derrick A. 1976. Serving Two Masters: Integration Ideals and Client Interests in School Desegregation Litigation. Yale Law Journal 85:470516.

Bellinger, John. 2014. In Spate of New ATS Decisions, Courts Are Divided About Meaning of Kiobel's "Touch and Concern" Standard. Lawfare blog, Sept. 28. http://www.lawfareblog.com/2014/09/in-spate-of-new-atsdecisions-courts-are-divided-about-meaning-of-kiobels-touch-andconcern-standard (accessed May 25, 2015).

Bennoune, Karima. 2011. The Paradoxical Feminist Quest for Remedy: A Case Study of Jane Doe v. Islamic Salvation Front and Anouar Haddam. International Criminal Law Review 11:579-87.

Bourdieu, Pierre. 1986. The Forms of Capital. In Handbook of Theory and Research for the Sociology of Education, ed. John G. Richardson, 241-58. New York: Greenwood Press.

Bumiller, Kristin. 1987. Victims in the Shadow of the Law: A Critique of the Model of Legal Protection. Signs 12:421-39.

Cabello-Barrueto, Zita. 2014. In Search of Spring: A Sister's Quest to Unearth the Truth About her Brother's Assassination by Chile's Caravan of Death. n.p.: CreateSpace Independent Publishing Platform.

Claude, Richard Pierre. 1983. The Case of Joelito Filártiga and the Clinic of Hope. Human Rights Quarterly 5:275-301.

Cleveland, Sarah. 2004. The Alien Tort Statute, Civil Society, and Corporate Responsibility. Rutgers Law Review 56:971-88.

Coliver, Sandra, Jennie Green, and Paul Hoffman. 2005. Holding Human Rights Violators Accountable by Using International Law in U.S. Courts: Advocacy Efforts and Complementary Strategies. Emory International Law Review 19:169-226. 
Collingsworth, Terry. 2002. The Key Human Rights Challenge: Developing Enforcement Mechanisms. Harvard Human Rights Journal 15:183-204.

Coffee, John. 2000. Class Action Accountability: Reconciling Exit, Voice, and Loyalty in Representative Litigation. Columbia Law Review 100:370-439.

Comaroff, John L., and Jean Comaroff. 2009. Ethnicity, Inc. Chicago: University of Chicago Press.

Curran, Vivian Grosswald, and David Sloss. 2013. Reviving Human Rights Litigation after Kiobel. American Journal of International Law 107:85863.

Dale, John G. 2011. Free Burma: Transnational Legal Action and Corporate Accountability. Minneapolis: University of Minnesota Press.

Dezalay, Yves, and Mikael Rask Madsen. 2012. The Force of Law and Lawyers: Pierre Bourdieu and the Reflexive Sociology of Law. Annual Review of Law and Social Science 8:433-52.

EarthRights International. 2005. Final Settlement Reached in Doe v. Unocal. http://www.earthrights.org/legal/final-settlement-reached-doe-v-unocal (accessed May 25, 2015).

Eisenberg, Theodore, and Charlotte Lanvers. 2009. What is the Settlement Rate and Why Should We Care? Journal of Empirical Legal Studies 6:111-46.

Felsteiner, William L. F., Richard L. Abel, and Austin Sarat. 1980/1981. The Emergence and Transformation of Disputes: Naming, Blaming, Claiming... Law \& Society Review 15:631-54.

Filártiga, Dolly. 2004. American Courts, Global Justice. New York Times, March 30. http://www.nytimes.com/2004/03/30/opinion/american-courts-globaljustice.html (accessed May 25, 2015).

Flyvberg, Bent. 2006. Five Misunderstandings About Case-Study Research. Qualitative Inquiry 12:219-45.

Folkenflik, David. 2010. A "Crude" Awakening: Chevron vs. The Documentarian. NPR All Things Considered, June 4. http://www.npr.org/templates/story.php?storyId=127410188 (accessed May 25, 2015).

Gabel, Peter. 1984. The Phenomenology of Rights-Consciousness and the Pact of the Withdrawn Selves. Texas Law Review 62:1563-99.

Garth, Bryant G. 1992. Power and Artifice: The Federal Class Action. Law \& Society Review 26:237-71.

Green, Jennifer M. 2014. The Rule of Law at a Crossroad: Enforcing Corporate Responsibility in International Investment Through the Alien Tort Statute. University of Pennsylvania Journal of International Law 35:1085-111.

Greer, Jed. 2001. Plaintiff Pseudonymity and The Alien Tort Claims Act: Questions and Challenges. Columbia Human Rights Law Review 32:51763. 
Harris, Theresa. 2008. Settling a Corporate Accountability Lawsuit Without Sacrificing Human Rights: Wang Xiaoning v. Yahoo!. Human Rights Brief 15:10-13.

Hoffman, Paul, and Beth Stephens. 2013. International Human Rights Cases Under State Law and in State Courts. UC Irvine Law Review 3:9-23.

Holzmeyer, Cheryl. 2009. Human Rights in an Era of Neoliberal Globalization: The Alien Tort Claims Act and Grassroots Mobilization in Doe v. Unocal. Law \& Society Review 43:271-304.

Johnson, Kevin R. 2004. International Human Rights Class Actions: New Frontiers for Group Litigation. Michigan State Law Review 2004:643-70.

Katotohanan at Katarungan Foundation. 1999. The Two Billion Dollar Human Rights Uproar: The Controversial Claims against the Marcos Estate and Insights into the Motives Deceptions of a Conspiracy of Vultures. Quezon City: Katotohanan at Katarungan Foundation.

Keck, Margaret E., and Kathryn Sikkink. 1998. Activists Beyond Borders: Advocacy Networks in International Politics. Ithaca, NY: Cornell University Press.

Kennedy, David. 2004. The Dark Sides of Virtue: Reassessing International Humanitarianism. Princeton, NJ: Princeton University Press.

Kennedy, Duncan. 2002. The Critique of Rights in Critical Legal Studies. In Left Legalism/Left Critique, ed. Wendy Brown and Janet E. Halley, 178-228. Durham, NC: Duke University Press.

Kriesi, Hanspeter. 1995. The Political Opportunity Structure of New Social Movements: Its Impact on Their Mobilization. In The Politics of Social Protest, ed. J. Craig Jenkins and Bert Klandermans, 167-98. Minneapolis: University of Minnesota Press.

Lakhani, Sarah Morando. 2013. Producing Immigrant Victims" "Right" to Legal Status and the Management of Legal Uncertainty. Law \& Social Inquiry 38:442-73.

Lutz, Ellen, and Kathryn Sikkink. 2001. The Justice Cascade: The Evolution and Impact of Foreign Human Rights Trials in Latin America. Chicago Journal of International Law 2:1-34.

MacKinnon, Catherine A. 2000. Collective Harms Under the Alien Tort Statute: A Cautionary Note on Class Actions. ILSA Journal of International \& Comparative Law 6:567-73.

Marshall, Anna-Maria, and Daniel Crocker Hale. 2014. Cause Lawyering. Annual Review of Law and Social Science 10:301-20.

Mattei, Ugo, and Jeffrey S. Lena. 2001. U.S. Jurisdiction Over Conflicts Arising Outside of the United States: Some Hegemonic Implications. Hastings International and Comparative Law Review 24:381-400. 
McCann, Michael W. 1994. Rights at Work: Pay Equity Reform and the Politics of Legal Mobilization. Chicago: University of Chicago Press.

Meili, Stephen. 2005. Cause Lawyering for Collective Justice: A Case Study of the Amparo Colectivo in Argentina. In The Worlds Cause Lawyers Make: Structure and Agency in Legal Practice, ed. Austin Sarat and Stuart A. Scheingold, 383-409. Stanford, CA: Stanford University Press.

Merry, Sally Engle. 1990. Getting Justice and Getting Even: Legal Consciousness Among Working-Class Americans. Chicago: University of Chicago Press.

Milner, Neal. 1986. The Dilemmas of Legal Mobilization: Ideologies and Strategies of Mental Patient Liberation Groups. Law \& Policy 8:105-29.

Moyn, Samuel. 2010. The Last Utopia: Human Rights in History. Cambridge, MA: Harvard University Press.

Mutua, Makau wa. 2002. Human Rights: A Political and Cultural Critique. Philadelphia: University of Pennsylvania Press.

Nader, Laura, and Harry F. Todd, Jr., eds. 1978. The Disputing Process: Law in Ten Societies. New York: Columbia University Press.

NeJaime, Douglas. 2011. Winning Through Losing. Iowa Law Review 92:9411012.

-----. 2012. The Legal Mobilization Dilemma. Emory Law Journal 61:663-736.

Posner, Eric. 2013. The United States Can't Be the World's Courthouse. Slate, April 24. http://www.slate.com/articles/news_and_politics/view_from chicago/2013/04/the_supreme_court_and_the_alien_tort_statute_ending_ human rights suits.html (accessed May 25, 2015).

Przeworski, Ā̄am. 1985. Capitalism and Social Democracy. Cambridge: Cambridge University Press.

Ratner, Morris. 2003. Factors Impacting the Selection and Positioning of Human Rights Class Actions in United States Courts: A Practical Overview. New York University Annual Survey of American Law 58:623-49.

Redford, Katie, and Beth Stephens. 2008. The Story of Doe v. Unocal: Justice Delayed but Not Denied. In Human Rights Advocacy Stories, ed. Deena R. Hurwitz, Margaret L. Satterthwaite, and Douglas B. Ford, 433-62. New York: Foundation Press.

Rhode, Deborah. 1982. Class Conflicts in Class Actions. Stanford Law Review 34:1183-262.

Riles, Annelise. 2011. Collateral Knowledge: Legal Reasoning in the Global Financial Markets. Chicago: University of Chicago Press.

Rosenberg, Gerald N. 1991. The Hollow Hope: Can Courts Bring About Social Change? Chicago: University of Chicago Press.

Sarat, Austin, and Stuart A. Scheingold. 2005. Introduction: The Dynamics of Cause Lawyering - Constraints and Opportunities. In The Worlds Cause 
Lawyers Make: Structure and Agency in Legal Practice, ed. Austin Sarat and Stuart A. Scheingold, 1-34. Stanford, CA: Stanford University Press.

Scheingold, Stuart A. 1974. The Politics of Rights: Lawyers, Public Policy, and Political Change. New Haven, CT: Yale University Press.

Shdaimah, Corey S. 2005. Dilemmas of "Progressive" Lawyering: Empowerment and Hierarchy. In The Worlds Cause Lawyers Make: Structure and Agency in Legal Practice, ed. Austin Sarat and Stuart A. Scheingold, 23973. Stanford, CA: Stanford University Press.

Simpson, Susan. 2013. Alien Tort Cases Resulting in Plaintiff Victories. The View from LL2 (Blog), November 11, 2009 (updated March 2013). http://viewfromll2.com/2009/11/11/ alien-tort-statute-cases-resulting-inplaintiff-victories/ (accessed May 25, 2015).

Southworth, Ann. 1999. Collective Representation for the Disadvantaged: Variations in Problems of Accountability. Fordham Law Review 67:244973.

Swift, Robert. 2013. A Short Memory. Philippine Daily Inquirer, 22 March. http://opinion.inquirer.net/49279/a-short-memory (accessed May 25, 2015).

Tarrow, Sidney. 2005. The New Transnational Activism. Cambridge: Cambridge University Press.

Tushnet, Marc. 1984. An Essay on Rights. Texas Law Review 62:1363-403.

van Schaack, Beth. 2004. With All Deliberate Speed: Civil Human Rights Litigation as a Tool for Social Change. Vanderbilt Law Review 57:230548.

Vanhala, Lisa. 2012. Legal Opportunity Structures and the Paradox of Legal Mobilization by the Environmental Movement in the UK. Law \& Society Review 46:523-56.

Ward, Ettie. 1988. The Litigator's Dilemma: Waiver of Core Work Product Used in Trial Litigation. St. John's Law Review 62:515-47.

Weekley, Kathleen. 1996. From Vanguard to Rearguard: The Theoretical Roots of the Crisis of the Communist Party of the Philippines. In The Revolution Falters: The Left in Philippine Politics Since 1986, ed. Patricio N. Abinales, 28-59. Ithaca, NY: Cornell Southeast Asia Program.

Weinstein, Jack B. 1994. Ethical Dilemmas in Mass Tort Litigation. Northwestern University Law Review 88:469-568.

\section{Marcos Litigation Documents (On file with author)}

Declaration of Daniel Vizmanos in support of motion to intervene. Makati, Philippines. Dec. 18, 1991.

Memorandum in Support of SELDA intervention in Hilao v. Marcos. Jan. 3, 1992. Plaintiffs' Memorandum Sur SELDA's Motion to Intervene. Jan. 13, 1992. 
United States District Court for the District of Hawaii. In re: Estate of Ferdinand E. Marcos Human Rights Litigation. Transcript of Proceedings. Jan. 20, 1992.

United States District Court for the District of Hawaii. In re: Estate of Ferdinand E. Marcos Human Rights Litigation. Transcript of Proceedings. April 29, 1999.

\section{STATUTE CITED}

Alien Tort Statute, 28 U.S.C. $§ 1350$ (1789).

\section{CASES CITED}

Doe v. Unocal Corp., 963 F. Supp. 880 (C.D. Cal. 1997).

Doe v. Unocal Corp., 67 F. Supp. 2d 1140 (C.D. Cal. 1999).

Filártiga v. Peña-Irala, 630 F.2d 876 (2d Cir. 1980).

Hunt v. Washington State Apple Advertising Commission, 432 U.S. 333 (1977).

Kiobel v. Royal Dutch Shell Petroleum Co., 133 S.Ct. 1659, 569 U.S.

National Coalition Government of Burma v. Unocal, Inc., 176 F.R.D. 329 (C.D.

Cal. 1997).

Roe v. Unocal Corp., 70. F. Supp. 2d 1073 (C.D. Cal. 1999).

\section{Brief}

Brief for the Center for Justice and Accountability, National Consortium of Torture Treatment Programs and Individual ATCA Plaintiffs and Amici Curiae in Support of Respondent, Sosa v. Alavarez-Machain, 542 U.S. 692 (2004). 


\section{NOTES}

1 "The Marcos litigation" refers to several different lawsuits, including a class action and two cases brought by individuals, which were tried together in the US District Court for the District of Hawaii in the early 1990s. In this article, I focus mainly on the class action.

2 Dale $(2011,171)$ reached a similar conclusion in studying the Unocal litigation, but emphasizes that success turned on how ATS litigation created risks for the corporate bottom line. Both Holzmeyer and Dale provide a helpful corrective to some other scholarship on ATS litigation (Johnson 2004; van Schaack 2004), which assumes litigants to be mobilizing for the human rights movement itself, rather than using ATS litigation as a tactic to mobilize some other type of movement.

${ }^{3}$ A case study by Bennoune (2011) of an ATS lawsuit against former leaders of fundamentalist organizations in Algeria offers a less sanguine perspective. The plaintiffs Bennoune interviewed were pleased that their case, despite its dismissal, had highlighted the struggles and suffering of women in Algeria. But their efforts to use the case as a basis for broader mobilization were limited (id., 585n11).

${ }^{4}$ Doing so can be disastrous for plaintiffs and their counsel. After being found liable for environmental pollution in Ecuador, Chevron sued a documentary filmmaker who had filmed the plaintiffs' legal team. It then used outtakes in its efforts to block enforcement of the judgment, and to sue the plaintiff's attorney (Folkenflik 2010; Barrett 2011).

${ }^{5}$ A few ATS plaintiffs have written op-eds (Filártiga 2004), memoirs (CabelloBarrueto 2014), or statements included in amicus briefs (Brief for Center for Justice and Accountability as Amicus Curiae, Sosa v. Alvarez-Machain, 2004).

${ }^{6}$ Class members later received a distribution of $\$ 1,000$ in 2011 , and again in 2014.

${ }^{7}$ Between 2005 and 2008, I worked as a law student and recent graduate on other ATS cases handled by these litigators, but never on the Marcos litigation itself. Since 2008, I have not been involved as an advocate in ATS cases.

${ }^{8}$ The newspaper clippings are archived in the Museum of Courage and Resistance, in the offices of Task Force Detainees of the Philippines, a human rights organization for which I interned over the summer of 2006.

${ }^{9}$ Probability sampling would have required access to the full list of claimants. This is available only to the district court in Hawaii and the lead class counsel, 
who estimates that $80 \%$ of claimants have died (Swift 2013).

${ }^{10}$ Recollections of dates were sometimes slightly off, but in general respondents' recollections of the sequencing and details of events fit closely with documentary evidence.

${ }^{11}$ The Tagalog name of the organization, Samahan ng Ex-Detainees Laban sa Detensyon at Aresto, was translated in court filings as the "Society of ExDetainees for Liberation Against Detention and for Amnesty."

${ }^{12}$ When pressed, Jovelyn and other respondents acknowledged that filing in the Philippines might have been possible, but it seemed certain that they would lose the case, since the judiciary remained filled with Marcos allies.

${ }^{13}$ After the huge awards of damages, Marcos loyalists would make hay of this point, publishing a book titled The Two Billion Dollar Human Rights Uproar: The Controversial Claims Against the Marcos Estate and Insights into the Motives and Deceptions of a Conspiracy of Vultures (Katotohanan at Katarungan Foundation 1999).

${ }^{14}$ In 1993, following the jury verdict finding the Marcos estate liable, activists confronted a similar dilemma - but now on a much broader scale. To become members of the class, the court required victims to fill out claim forms. Over 10,000 such forms were filed, but according to an elected official, "a significant number have refrained from joining the class suit on a very strong position that they would like to seek justice not through the US court" (Interview with Daniel, Quezon City, Aug. 1, 2006). Others opted not to file forms because they thought their suffering could not or should not be monetized (Interviews with Marites, Quezon City, July 12, 2006, and with Rizal, July 9, 2006).

15 The class action included three sub-classes: one for survivors of torture, and others for next of kin of people killed or disappeared by the Marcos regime.

${ }^{16}$ Sison recalled that his lawyer told him during his deposition to stop trying to score political points, because it could jeopardize the success of his lawsuit.

${ }^{17}$ As an ATS plaintiff in a different case has observed, "a lawsuit reveals a great deal, but it is ultimately about winning, not presenting a complete historical record" (Cabello-Barrueto 2014, xvii).

${ }^{18}$ As Mutua (2002) might put it, they assumed the role of helpless victims, and allowed their attorneys to portray Marcos and his regime as the savage; yet some activists pushed back when Swift sought to assert his role as savior.

${ }^{19}$ If Swift had signed, he arguably would have been jeopardizing the interests of absent class members. 
20 "From the inception of this case," Swift wrote, "SELDA was not considered a plaintiff because it lacks standing. The class case seeks damages on account of personal injuries suffered by individuals, and only those individuals are proper plaintiffs" (Plaintiffs' Memorandum Sur SELDA's Motion to Intervene 1992, 2 $3)$.

${ }^{21}$ In this respect, the experience of many respondents in the Marcos litigation even people who simply filed a claim, and never appeared in court - parallels other accounts (Filártiga 2004; Aceves 2007; Bennoune 2011) that have observed how ATS litigation gives plaintiffs meaningful opportunities to tell their stories.

22 They chose the name in memory of Proclamation 1081, in which Marcos had declared martial law.

${ }^{23}$ Aided by SELDA, other human rights groups, and students who volunteered to enter data, Swift had built a database with information on thousands of potential claimants (Interview with Robert Swift, Mar. 22, 2007).

${ }^{24}$ SELDA members saw these clauses as letting the Marcos family off the hook. SELDA has not opposed other attempts at settlement, including Swift's negotiations with people who have come into possession of Marcos assets.

${ }^{25}$ There has not been a comprehensive summary of the settlement rate in ATS cases. A review of ATS cases that survived dismissal up to 2013 suggests that plaintiffs who sued individuals were more likely to win through a default judgment or a trial than through a settlement, while nearly all the successful suits against corporations ended in settlement (Simpson 2013). 